\title{
Gendered Constructions of Professionals in Daycare
}

\author{
Greetje Timmerman $\cdot$ Pauline Schreuder
}

Published online: 1 May 2008

(C) The Author(s) 2008

\begin{abstract}
In The Netherlands the boys' problem debate in education has expanded to daycare, concerning the children between 0 and 4 years of age. Women daycare workers are blamed by mainstream media for frustrating boys' need for physical activity and adventure. In 2004 we conducted a study, involving 96 daycare workers in 36 daycare centers in a Dutch city. We addressed the research question whether the stereotypical representation of women's daycare work in the media is an adequate picture of these professionals' perceptions of their work in daycare. Findings indicate that the stereotypical images of women daycare workers in the media-debates do not resemble the personal qualities and professional characteristics that these daycare workers ascribe to themselves.
\end{abstract}

Keywords Gender·Professionals · Daycare

\section{Introduction}

In the wake of recent media discussions on boys' problems in primary and secondary education, mainstream media in The Netherlands portray female daycare workers as dangerous for a healthy development of young boys in daycare too. The purpose of this survey among 96 women

\footnotetext{
G. Timmerman $(\varangle) \cdot$ P. Schreuder

Faculty of Behavioural and Social Sciences,

University of Groningen,

Grote Rozenstraat 38,

9712 TJ Groningen, The Netherlands

e-mail: m.c.timmerman@rug.nl

P. Schreuder

e-mail: p.r.schreuder@rug.nl
}

daycare workers was to explore how the women themselves perceived the qualities that their work requires. Our research question was to what extent women workers' perceptions of their work in daycare are in line with common gender stereotypical contructions by the media? Results show that women workers in daycare view their work from a broad professional perspective. As such, the study challenges the essentialism underlying the recent stereotypical media constructions of women workers in daycare.

In many countries in Western Europe, USA, Canada and Australia recent debates about the feminization of teaching have addressed the sex of the teachers as one of the main causes of boys' educational or behavioral problems (Epstein et al. 1999; Foster et al. 2001; Ginsberg et al. 2004; Francis and Skelton 2005; Robinson et al. 2006). Women teachers are said to be too 'feminine' in their behavior, and men teachers are proposed as the solution to the problem of the feminization of the teaching force (Cameron et al. 1999; Foster et al. 2001; Murray 1996).

Surprisingly, only in The Netherlands these debates on boys' problems have expanded to daycare, concerning the children between 0 and 4 years of age. Daycare for young children has been the exclusive territory of women for a long time, but - contrary to primary and secondary education (Timmerman and van Essen 2004) - the sex of the caretakers has never been considered to be a problem. However, in the wake of the Dutch media debates on boys' problems in education, female daycare workers are now attacked for creating a feminized culture in daycare centres. This debate started in January 2003, but got full national attention from March 11, 2003 onwards, when one of the Dutch quality newspapers published a major article on this issue, stating that "female daycare workers identify themselves mostly with the girls, and are annoyed by the 
adventurous play of boys, thus putting boys at a serious developmental disadvantage" (De Volkskrant 2003). Their 'feminine' behavior allegedly consists of having no patience with rough and tumble play or with shouting or running around, and of placing restrictive demands on all children, in order to keep the playroom quiet and neat at all times (De Volkskrant 2003, p. 9). Boys, on the other hand, are said to be adventurous and like to improvise and experiment with materials. Often, women daycare workers will react annoyed and angry, the newspaper continues, and will call the boys to order: "The boys are in fact not allowed to be boys and to do what boys do" (Leids Dagblad 2003). The 'predominantly female culture' in the daycare sector, where control, calm and order are supposed to reign, is supposed to seriously frustrate the boys' need for physical activity, with disastrous consequences: “...if young boys receive negative feedback from women for too long, they will eventually stop taking notice of the rules" (NRC 2004). Critical reactions to this discourse in the Dutch debate (Volman 2004) seem to have less appeal than the essentialistic, 'common-sense' type of arguments of the discourses that depict women caretakers as unprofessionally trapped in their own gender-identity, and therefore potentially dangerous to young boys.

Furthermore, these stereotypical media-images are supported by psychotherapists, psychologists and educationalists, thereby reinforcing the public questioning of the professional capacities of women caretakers in early childhood education and daycare. When young boys are forced to behave as if they were girls, the assumption holds, this could be a serious risk to their nature, and their identity development (Woltring 2003). Boys, according to Louis Tavecchio, who holds a chair on daycare at the University of Amsterdam, "need to be around men in order to see how to shape their masculine behavior. Every developmental theory teaches us this. Instead, they have to meet what I call the girls'standard. Because girls are the perfect pupils: docile, diligent, and cooperative. Boys don't meet this standard. What's more, boys are unable to meet this standard." (Tavecchio, quoted in De Volkskrant 2003). According to the well-known Dutch educational sociologist Jungbluth it is not only 'discipline,' but also 'modesty,' 'care,' and 'conflict avoidance' that describe how women workers in (early) education deal with young children (NRC 2003). Therefore, 'male' daycare staff is required, as they allegedly will 'romp around' more with the children, will encourage 'enterprising behavior,' and will show more humor: "men make more jokes" (NRC 2003).

In the public discourse on daycare the assumption that being a woman is a natural and sufficient qualification for caring for children, has carried a long tradition. However, the characteristics on which this assumption was based, have not always been defined as being typically 'female.'
Certain characteristics were at times considered to be 'typically female,' and at other times 'typically male,' for instance 'maintaining discipline.' In the recent Dutch media debates on daycare, 'discipline' is one of the characteristics that are thought to dominate the way in which women staff deal with children: 'Women like structure and discipline. They like to plan' (Noordhollands Dagblad 2003). In the second half of the nineteenth century however, the supposed lack of discipline was the very reason that, under the terms of the Education Act of 1878, Dutch women teachers were preferably deployed in primary classes (van Essen 1999). Teachers in senior classes had to be capable of maintaining class discipline, especially among the older boys, and this was said to be a job for men teachers only. In primary education, these notions have also prevailed for many years. Nowadays, men teachers and caretakers are supposed to hold a certain disregard for structure and discipline, and are thought to provide children, particularly boys, with the physical activity that is supposed to be so essential to them (NRC 2004; Noordhollands Dagblad 2003).

\section{Gender and Professionalism in the Work of Women Daycare Workers}

Early childhood professionals (e.g. nursery workers) have long been viewed as surrogate mothers (Singer 1992; Cameron et al. 1999; Browne 2004). In the early nineteenth century, the Dutch school inspector Visser wrote the first manual for daycare-keepers (as they were called in that time) in The Netherlands, in which he described that being a good and hygienic housekeeper, as well as being kind, patient and understanding towards young children, were the professional qualities that were mainly required (Clerkx and Pot 1987). According to the Dutch pedagogue Singer (1992), herein lies the root of the romantic image of motherliness as the main characteristic of the professional identity of daycare staff. This emphasis on motherliness has grown throughout the main part of the 20th century, under the influence of Bowlby's attachment theory (Singer 1992). In The Netherlands, this ideal of motherliness for daycare staff has remained particularly persistent. Therefore, if women did have to go out to work, their children would be best left in the care of surrogate-mothers, in daycare settings. This image of the surrogate-mother has only gradually given way to the view of daycare-workers as educational professionals (Vandenbroeck 2004).

The continued media construction of the professionalism of staff in the daycare sector as a mix of 'female' traits for which little training is needed, is detracting from the changes that have been taking place in the sector for some time now. In The Netherlands, (as well as in surrounding countries such as Belgium), one of the most striking 
changes in the past 30 years is that greater emphasis is now being placed on the pedagogical aspects of childcare. According to recent pedagogical quality criteria (RiksenWalraven 2000), staff must not only create an environment that provides both physical and emotional care and security, but they are also responsible for the personal, emotional and social development of children (Dowling 2000; NICHD 2002) and for passing on cultural standards and values (Tavecchio 2002). Let us assume that this explicit pedagogical orientation in the field has also permeated through to the professional attitudes of daycare staff, and that the ideal image of motherliness, characterised by love and care, has been replaced by a professional attitude that emphasizes the aspect of upbringing and the development of children. This new pedagogical focus should then be reflected in the choice for a broad range of developmental activities that women caretakers consider to be important for children: developmental activities that address cognitive, emotional, as well as social and communicating activities. In this early childhood research literature this pedagogical orientation of daycare workers is described in terms of stimulating developmental activities like reading to children, singing, imaginative play, building with contruction materials, drawing, etc., in line with so-called Developmentally Appropriate Practice (DAP; MacNaughton 2000; Dowling 2000; Riksen-Walraven 2000; Tavecchio 2002).

The tendency towards gender stereotyping of women daycare workers by the mainstream media enforces the traditional view that women's work in daycare requires no other qualities than 'the female sex.' By equating 'sex' and 'gender,' the media assume that 'sex'-by nature or biology-implies gender stereoypical qualities. Because of their sex, women who work with young children in daycare are supposed to display gender stereotypical qualities, such as a 'motherly' caring orientation towards their work, thereby restricting boys' need for more 'masculine' role models. However, as the professionality of daycare work has expanded from an almost exlusive focus on 'femininity' (e.g. motherliness) and a (motherly) caring orientation towards a broad pedagogical orientation on the cognitive, social and emotional development of the children, we need a concept of daycare work that encompasses a broad spectrum of personal as well as professional qualities. This broad perspective of women's professional work in daycare opens up the possibility to question the essentialism underlying the recent media constructions of women's work in daycare. By exploring women's own views we aim to show that their sex does not 'by nature' stands for a 'feminine' way of doing daycare work. The research question in this study was to examine to what extent women workers' perception of their work in daycare is in line with common gender stereotypical contructions by the media.
The Present Study

Before proceeding, we would like to note that this study builds on the results of a pilot study that was conducted a year before the present one (Timmerman and Schreuder 2005; Timmerman and Schreuder 2008). The pilot study investigated the views of 83 trainees in daycare, who attended three different colleges, in the city of Groningen, The Netherlands. Although they did have some work experience, these respondents were relatively 'new to the job.' The trainees views on their (future) work indicated that they considered "being like a mother" rather important ( $75 \%$ agreed to this statement), however, at the same time they thought men would be equally suitable for this job as women $(86 \%$ agreed to this statement). They clearly favored the stimulation of language development as most important developmental activity, but outdoor play was mentioned as a close second. The most important professional characteristics, according to these trainees, were 'responsibility,' 'caring,' 'loving children,' 'being active' and 'humor.' In short, these trainees showed a rather differentiated view on child care workers.' This modern, differentiated view could be related to the fact that they are still in training, and therefore may be taught the most recent views of daycare. We were interested in finding out whether these views are also held by professionals with more experience in daycare. The questionnaire that was used in the pilot study needed a few alterations before we could use it on our present study. These alterations consisted mainly of a more precise operationalisation of the caring aspects of the job, using Vogt's different aspects of care (Vogt 2002).

The aim of the present study was to explore women workers' perception of their work in daycare. In many countries boys' problems have been attributed to the feminization of the teaching force, but the current debate about negative effects of an exclusively female staff in daycare centers seems to be the unique situation in The Netherlands. Throughout the twentieth century, daycare continued to be staffed by women and this was not seen as a problem, until recently. Our study is important because current media-debates seem to succeed in dominating the public opinion, thereby distracting from the professional developments in childcare that have taken place of the past decades. This study is one of the first studies that addresses women's work in daycare centers as professional work.

Using a concept of professionalism that includes personal qualities as well as professional characteristics (a care orientation and a pedagogical orientation) we addressed the research question whether the stereotypical representation of women's professional and personal characteristics is an adequate picture of these professionals' opinions of their work in daycare. As such, the study focused 
on womens' perception of the qualities and characteristics they regard as important to their work in daycare centers. Based on the researchliterature (Hoogeveen 1999) and the media-debates discussed in the introduction we advanced the following three hypotheses:

Hypothesis (1): women daycare workers perceive 'feminine' qualities as more important to their work than other personal qualities.

Specifically, we hypothesized that women daycare workers perceive the typical 'feminine' traits 'care,' 'modesty,' and 'hominess' as more important than typical 'male' traits ('a sense of humor,' 'resourcefulness') and other personal characteristics that have been considered as necessary for a good daycare worker, women or men: 'a love of children,' 'a sense of responsibility' and 'intelligence.' Seperately, each hypothesis was formulated as follows:

Hypothesis (1a): women daycare workers perceive 'caring' as more important to their work than other personal qualities.

Hypothesis (1b): women daycare workers perceive 'modesty' as more important to their work than other personal qualities.

Hypothesis (1c): women daycare workers perceive 'hominess' as more important to their work than other personal qualities.

Hypothesis (1d): women daycare workers perceive 'preference for structure' as more important to their work than other personal qualities.

To examine women daycare workers care-orientation we used the concept of 'care-orientation' as employed in early childhood research literature by Vogt (2002), consisting of a 'typical feminine' aspect (e.g. 'motherly' careorientation) as well as more 'gender neutral' aspects of care: care as 'commitment,' as 'relatedness,' as 'physical' care, as 'expression,' and care as 'parenting.'

Hypothesis (2) women daycare workers rate the specific 'typical feminine' care-orientation (e.g. a 'motherly' care-orientation) to their work higher than a broad care-orientation.

Formulated seperately, the hypotheses are:

Hypothesis (2a): women daycare workers rate the specific 'typical feminine' care-orientation (e.g. a 'motherly' care-orientation) to their work higher than care as 'commitment.'

Hypothesis (2b): women daycare workers rate the specific 'typical feminine' care-orientation (e.g. a 'motherly' care-orientation) to their work higher than care as 'relatedness.'

Hypothesis (2c): women daycare workers the specific 'typical feminine' care-orientation (e.g. a 'motherly' care-orientation) to their work higher than care as 'physical care.'

Hypothesis (2d): women daycare workers the specific 'typical feminine' care-orientation (e.g. a 'motherly' care-orientation) to their work higher than care as 'expression.'

Hypothesis (2e): women daycare workers the specific 'typical feminine' care-orientation (e.g. a 'motherly' care-orientation) to their work higher than care as 'parenting.'

Hypothesis (3): women daycare workers perceive stimulating so-called 'typical feminine' developmental activities as more important than 'masculine' or 'gender-neutral' developmental activities, for girls as well as for boys.

Based on the pedagogical researchliterature, this hypothesis specifically examines a broad range of developmental activities that address cognitive, emotional, as well as social and communicating activities: 'building with construction materials' (blocks, Lego), 'drawing and coloring,' outdoor play ('letting off steam, running, shouting'), 'imaginative play,' 'sandpit play,' 'handiwork,' 'playing house,' 'helping with domestic chores' (sweeping the floor, setting the table at snack time), 'dressing-up play,' 'helping each other,' 'romping around,' 'reading and singing' (Developmentally Appropriate Practice [DAP]; MacNaughton 2000; Dowling 2000; Riksen-Walraven 2000; Tavecchio 2002). Formulated seperately, we advanced the following hypotheses:

Hypothesis (3a): women daycare workers perceive 'handiwork' as a more important developmental activity, for girls as well as for boys, than other developmental activities.

Hypothesis (3b): women daycare workers perceive 'dressing-up' as a more important developmental activity, for girls as well as for boys, than other developmental activities.

Hypothesis (3c): women daycare workers perceive 'reading to children and singing' as a more important developmental activity, for girls as well as for boys, than other developmental activities.

Hypothesis (3d): women daycare workers perceive 'doing household chores' as a more important developmental activity, for girls as well as for boys, than other developmental activities.

Hypothesis (3e): women daycare workers perceive 'colouring, drawing' as a more important developmental activity, for girls as well as for boys, than other developmental activities. 
Hypothesis (3f): women daycare workers perceive 'playing house' as a more important developmental activity, for girls as well as for boys, than other developmental activities.

In order to test these hypotheses we have conducted a survey among women daycare workers, using a questionnaire. Nearly all questions were closed-option questions. Next to this type of questions we also made use of two scenarios, describing everyday practice in daycare.

\section{Method}

\section{Participants}

In 2004 we conducted a study, involving 96 women daycare workers in 36 daycare centers in the city of Groningen (pop. 180,000), in the north of The Netherlands. At that time, Groningen had 51 daycare centres, 49 of which were asked to participate in this study, as two research assistents were parttime employees of two daycare centres. Thirteen of the approached centres did not want to participate or were unable to, for several reasons (lack of time, lack of interest etc.), so in the end 36 daycare centres were included in the study. At each centre, three childworkers were asked to fill in the questionnaire; one small centre had only two employees, at three other centres the daycare workers themselves asked for a fourth questionnaire to fill in. Research assistents introduced and distributed the questionnaires in person, and collected them a week later. Of the 107 questionnaires that were distributed, 96 were returned: a response rate of $90 \%$.

\section{Questionnaire}

The questionnaire was divided into various sections: first, general information about the respondent, secondly, we investigated personal characteristics, a care orientation and a pedagogical orientation directed to the stimulation of developmental activities in the daycare centre. The items in the three quantitative measures were put in a random order.

At the end of the questionnaire questionnaire, two scenarios were added: two short, staged scenes based on practical situations in a daycare centre.

The items in the questions were classified according to:

- Personal characteristics. This subsection inquired about the personal characteristics of a good daycare worker, according to the respondents. The items in the first question were partly derived from the stereotypical 'feminine' and 'masculine' characteristics that were suggested by recent media-debates on daycare and boys' problems in The Netherlands (Noordhollands
Dagblad 2003; Leids Dagblad 2003; NRC 2003, 2004; De Volkskrant 2003). The selection of media-images consisted of:

- 'Typically female' personal characteristics as 'caring,' 'modesty,' 'hominess,' 'preference for structure' (characteristics attributed to women daycare workers)

- 'Typically male' personal characteristics as 'humor,' 'resourcefulness,' 'being active' (characteristics that men daycare workers are assumed to possess)

Besides these items from media-stereotypes, items for this question about personal characteristics of a daycare worker were also derived from daycare research in The Netherlands that found three characteristics essential for women as well as men primary teachers and daycare workers: 'a love of children,' 'a sense of responsibility' and 'intelligence' (Hoogeveen 1999). These three characteristics are defined as 'gender-neutral,' because they were found to be important for women as well as men early child educators. In sum, this question enquiring after important personal characteristics consisted of ten items, 'feminine' (four items), 'masculine' (three items) and three 'genderneutral' items, presented in a random order.

Each item was measured by askind th erespondents to prioritise the items on a scale of 1 to $5(1=$ not at all important, $2=$ unimportant, $3=$ neither important nor unimportant, $4=$ important, $5=$ very important). To test which items measured 'feminine' or 'masculine' characteristics we used factor-analysis as well as reliability tests of internal consistency. Neither of these approaches indicated a group of items that measured the same construct. For instance, Cronbach's alpha for 'feminity' items was .54 and for 'masculinity' items .41 , suggesting that they do not address the same underlying concept. As such, these test results underline that the media-images of 'typical female' and 'typical male' characteristics of daycare workers are constructions that do not refer to a concept of feminity or masculinity. Therefore, we use the separate items in this study.

- Professional characteristics. A distinction was made in the professional characteristics between a care orientation and a pedagogical orientation (Tavecchio 2002; Vogt 2002; van IJzendoorn et al. 2004).

- Care orientation. We used the care concept as a multi-layered concept as explored by Vogt (2002, p. 251): caring as 'commitment,' as 'relatedness,' as 'physical care,' as 'expression,' as 'parenting' and as 'mothering.' The question was how important the various caring aspects were perceived by daycare staff. The respondents were given six statements in a random order, to which they could respond on a five-point scale $(1=$ 
totally disagree, 5=totally agree). Cronbach's alpha was .66, indicating a weak scale, therefore we used the items seperately.

- Pedagogical orientation. The pedagogical orientation of future daycare workers was examined by means of two questions. The first question examines the respondents' views on stimulating children's development, which is considered to be one of the main tasks of daycare workers. The question consists of 12 items inquiring into all kinds of developmental activities (Dowling 2000; Riksen-Walraven 2000; Tavecchio 2002). The question was formulated as follows. "Providing developmental activities for young children is considered to be an important function of daycare centres. How do you rate the importance of the developmental activities listed below?" This was followed by a list of 12 activities in random order, designed to stimulate development: 'building with construction materials' (blocks, Lego), 'drawing and coloring,' outdoor play ('letting off steam, running, shouting'), 'imaginative play,' 'sandpit play,' 'handiwork,' 'playing house,' 'helping with domestic chores' (sweeping the floor, setting the table at snack time), 'dressing-up play,' 'helping each other,' 'romping around,' 'reading and singing'). Respondents were asked to prioritise these $(1=$ not at all important, $2=$ unimportant, $3=$ neither important nor unimportant, $4=$ important, $5=$ very important). They were then asked to indicate which 5 characteristics from the list were the most important, in order of priority (a top five). The Cronbach's alpha of this scale was .77 .

In the daycare debates some developmental activities are labelled as 'typically boyish' and some as 'typically girlish' behavior. For instance, 'typically boyish' behavior was reflected in the items 'room to romp around with each other,' 'space to let off steam outside,' 'the availability of building materials (building blocks) and imaginative games with cars and trains.' Activities that-according to the media-debates attributed to 'typically girlish' behavior were: 'handiwork,' 'dressing-up,' 'reading to children, singing,' 'doing household chores' (laying the table, sweeping the floor); 'colouring, drawing'; 'playing house' (cooking, eating, sleeping). The Cronbach's alpha's for both scales were rather low (.64 for the femininity scale and .65 for the masculinity scale). Therefore we used the separate items.

- Scenarios. Apart from a questionnaire, we used another method to explore our research question whether the media stereotypical representation of women's professional and personal characteristics is an adequate picture of these professionals' opinions of their work in daycare.
Although observation of staff at work would give the most reliable impression of routine behaviour in daycare centres, the short-term nature of our study precluded this type of research. Therefore, as final part of the questionnaire, we presented the respondents with a number of staged but commonplace practical situations (scenarios) in which daycare workers interact and communicate with children. The choice of scenarios was based upon discussions in the media about how women daycare staff reputedly approach children (preferring quiet indoor activities, rigidly holding on to rules etc.). In the scenarios, two fictitious daycare workers each prefer a different approach; the respondents were asked which approach they would choose themselves, and why.

\section{Scenario 1}

It is a dull autumn day. Although a bit cold, it is not raining. The 'Sunflower' daycare centre has 12 children in its toddler group (2-4 years old) today: nine boys and three girls. Daycare workers Nathalie (21) and Linda (29) are on duty. They have just eaten fruit together and the children are playing. They are very excitable today: there is a lot of pushing and shouting, and a few arguments and tears. Linda and Nathalie both want to do something to improve the atmosphere.

Daycare worker Linda suggests that everyone sits at the big table to play with clay. They could play some cheerful music and restore the calm.

Daycare worker Nathalie would rather take the children outside to play. They could let off steam, run around and shout, and work off some of their excess energy. She thinks that this would also improve the atmosphere inside.

The respondents were asked how they would react: which of the two daycare workers in the scenarios acted as the respondents would have done? Would they act as Linda, a calm, orderly activity, or as Nathalie, who chose a noisy activity? In the media-debates on daycare, women caretakers are assumed to choose the calm, orderly (e.g. the traditional feminine) option.

\section{Scenario 2}

In the area for toddlers (2-4 years old), there is a chest that is used for storing cardboard boxes, toilet rolls and other materials for creative handiwork. Three boys have taken a box from the chest and say that they want to make something. This is fine, but only after the table has been cleared. They will have to wait.

The boys do not mind. Niels calls out: 'I've got a racing car!,' and gives his box a hard push so that it flies across the floor to the other end of the room. Jordi and Kevin start to yell and shout and soon all three boys are enjoying a wild, noisy race with the 'racing car' boxes. 
Daycare worker Sharon: "Kevin, Niels and Jordi, you know perfectly well that the boxes are not meant for racing. Either come and sit at the table and make something with them, or put the boxes back in the chest. We have plenty of cars for racing, and you don't have to shout so loudly."

Daycare worker Bernice: "Hey, are you having a race? I didn't know we had a racetrack here! I have an idea, let's move the race out into the corridor. There's more room there, and we'll be able to go much faster. Can I join in? I'll just go and choose a 'car.",

Scenario 2 also reflects the media-discourse on female daycare workers in the reaction of daycare worker Sharon. She resembles the rigid female daycare worker who continuously restricts boys' need for activity and movement. Bernice, on the other hand, chooses the 'masculine' option, characterized as such in the media-debates. Male early childhood educators are assumed to be better equipped to daycare for boys or to primary teaching, because they are said to acknowledge boys' need for activity.

Next to the choice between the typical 'feminine' or 'masculine' option to handle the situation in the scenarios, respondents were also asked to indicate why they preferred one or the other 'solution.' We presented them with three (scenario 1) and four (scenario 2) items indicating motivations they might have for their choice. In the case of the first scenario these were the following two items: 'age and experience of the daycare workers,' 'having to clean up sand and dirt after outdoor play,' and 'boys need more physical activity than girls.' In case of the second scenario, the items were: 'appreciation of the child's initiative,' 'taking the wild and noisy play to the corridor is a good solution,' 'it is important to express clearly what is and what isn't allowed,' and 'boys are just more physical and need more space.' The respondents were asked whether they thought these arguments were important or unimportant. Finally, the respondents were asked if they would choose differently if the scenarios were about a situation with more girls than boys (first scenario), or about girls instead of boys (second scenario).

\section{Results}

\section{Personal Characteristics}

Daycare workers were first asked to indicate which personal characteristics they considered to be important for a professional daycare worker (Table 1).

In accordance with the research literature on developments in daycare workers' professional identity, we hypothesized that - contrary to media discourses in The Netherlands - respondents would not rate 'feminine' characteristics as more important than 'masculine' or more
Table 1 Important personal characteristics.

\begin{tabular}{llll}
\hline Personal characteristics $(N=96)$ & Mean & SD & SE \\
\hline Responsibility & 3.98 & .14 & .14 \\
Loving children & 3.95 & .26 & .27 \\
Caring & 3.87 & .37 & .14 \\
Being active & 3.64 & .56 & .06 \\
Humor & 3.55 & .60 & .06 \\
Resourcefulness & 3.38 & .67 & .06 \\
Hominess & 3.33 & .76 & .08 \\
Structure & 3.33 & .70 & .07 \\
Intelligence & 2.71 & .78 & .08 \\
Modesty & 2.37 & .78 & .08 \\
\hline
\end{tabular}

$N=96 ; 5=$ very important, $1=$ not at all important

gender-neutral characteristics. Table 1 shows that respondents value almost all mentioned characteristics of a professional daycare worker, but 'responsibility' $(M=3.98$, $\mathrm{SD}=.14)$, 'loving children' $(M=3.95, \mathrm{SD}=.26)$ and 'caring' $(M=3.87, \mathrm{SD}=.37)$ are ranked highest, followed by 'being active,' 'humor,' 'resourcefulness,' 'hominess' and 'structure.' Of the few characteristics that are considered less important, 'modesty' $(M=2.37, \mathrm{SD}=.78)$ is rated as the least important characteristic for a good daycare worker.

Of the three highest valued characteristics, two are 'gender-neutral': responsibility and loving children, whereas 'caring,' traditionally depicted as a 'typically female' characteristic, comes in third place. Contrary to hypothesis 1 , respondents do not rate 'typical feminine' qualities - so defined by the mainstream media-as more important than other personal qualities. Instead, the five most important characteristics are a combination of 'typical feminine' (care), 'gender-neutral' (responsibility, loving children) and 'typical masculine' characteristics (being active and humor). Overall, the respondents indicate that the range of valuable characteristics for a daycare worker, is broad rather than narrow and gender-specific.

\section{Professional Characteristics}

\section{Care Orientation}

The care orientation is subdivided into six aspects, ranging from gender-neutral to stereotypically 'female': being involved in one's work, feeling connected to children, physical care of children, giving hugs and cuddles, being like a parent, and being like a mother. The respondents were presented with six statements to gauge their opinions on care. The statements were formulated in terms of characteristics of a good daycare worker: '...... is involved in her/his work,' '.....feels connected to children,' '.....pays a lot of attention to the physical care of children,' '.....often gives hugs and cuddles to the children,' '..... is like a parent 
to the children,' and '....is like a mother to the children' (Table 2).

Following Vogt (2002, we hypothesized that women daycare workers would employ a 'typical feminine' careorientation to their work, i.c. a 'motherly' care-orientation. Table 2 shows that respondents agree most with two other statements: 'being involved' $(M=3.82, \mathrm{SD}=.83)$ and 'feeling connected' $(M=3.82, \mathrm{SD}=.83)$. They agreed least with the statements on 'being like a mother' $(M=2.21, \mathrm{SD}=$ $2.21)$ or 'like a parent' $(M=1.46, \mathrm{SD}=1.17)$. Interestingly, and contrary to hypothesis 2 , the most popular statements are related to 'gender-neutral' care orientations, whereas the respondents agree least on the more 'typically female' careorientation, e.g. the 'motherly' care-orientation.

\section{Pedagogical Orientation}

Providing developmental activities One of the recent media assumptions about the negative effects of the excessive numbers of women in the daycare sector is that boys are not given enough space for 'typically boyish' behavior: running around, physical activities, etc. Daycare workers are allegedly stimulating children only in certain areas of their development, i.e. calmer and more passive activities such as reading, handiwork, etc. This is thought to create a predominantly 'female' environment, which is stunting boys in their development.

To explore these assumptions we formulated a third hypothesis: "Women daycare workers perceive stimulating so-called 'typical feminine' developmental activities as more important than 'masculine' or 'gender-neutral' developmental activities, for girls as well as for boys," with separate hypotheses for each of the items.

Hypothesis (3a): women daycare workers perceive 'handiwork' as a more important developmental activity, for girls as well as for boys, than other developmental activities.

Hypothesis (3b): women daycare workers perceive 'dressing-up' as a more important devel-

Table 2 Aspects of care orientation.

\begin{tabular}{llll}
\hline Statement & Mean & SD & SE \\
\hline Being involved & 3.82 & .83 & .04 \\
Feeling connected & 3.82 & .83 & .04 \\
Physical care & 3.30 & .65 & .07 \\
Hugs and cuddles & 3.06 & .75 & .08 \\
Being like a mother & 2.21 & 1.34 & .14 \\
Being like a parent & 1.46 & 1.17 & .12 \\
\hline
\end{tabular}

$N=96 ; 1=$ strongly disagree, $5=$ strongly agree opmental activity, for girls as well as for boys, than other developmental activities.

Hypothesis (3c): women daycare workers perceive 'reading to children and singing' as a more important developmental activity, for girls as well as for boys, than other developmental activities.

Hypothesis (3d): women daycare workers perceive 'doing household chores' as a more important developmental activity, for girls as well as for boys, than other developmental activities.

Hypothesis (3e): women daycare workers perceive 'colouring, drawing' as a more important developmental activity, for girls as well as for boys, than other developmental activities.

Hypothesis (3f): women daycare workers perceive 'playing house' as a more important developmental activity, for girls as well as for boys, than other developmental activities.

We asked the daycare workers to indicate the importance of several developmental activities (Table 3).

First, the results in Table 3 clearly show that all the activities are at least considered to be more or less important by the women daycare workers. Most important developmental activities are 'letting off steam' $(M=3.93$, $\mathrm{SD}=.26)$ and 'reading to children, singing' $(M=3.91$, $\mathrm{SD}=.32)$, 'imaginative play' $(M=3.77, \mathrm{SD}=.42)$, 'construction play' $(M=3.75, \mathrm{SD}=.44)$, and 'playing in the sandpit' $(M=3.73 S D=.51)$ whereas 'drawing and coloring,' 'handiwork' and 'playing house' are considered to be a little less important. 'Helping each other' $(M=3.24, \mathrm{SD}=.75)$ and 'helping out with domestic chores' $(M=2.95, \mathrm{SD}=.71)$, such as sweeping the floor and cleaning the table after snack time, are considered least important in this list of activities.

When asked to indicate a 'top-five' of activities, the results were as follows (Table 4):

Again, 'letting off steam' and 'reading to children, singing' are clearly considered to be the most important developmental activities. Not only are these activities frequently chosen as first and second choice, but they are also chosen by most respondents $(88 \%$ and $90 \%$ respectively, as shown in the last column of the table). 'Imaginative play with cars and trains' follows at a certain distance (a total of 53\%), and is almost equally often chosen in each place. Some activities are hardly chosen at all in the 'top-five': 'helping with chores' and 'dressing up.' The other activities make up the middle field of choices.

From both aspects of the question on developmental activities (Tables 3 and 4) it shows that the daycare workers value a broad range of these activities. Within this range, two activities are clearly considered to be most important: 
Table 3 Developmental activities.

\begin{tabular}{llll}
\hline Developmental activity & Mean & SD & SE \\
\hline Letting off steam outside (running, shouting etc.) & 3.93 & .26 & .03 \\
Reading to children, singing & 3.91 & .32 & .03 \\
Imaginative play with cars, trains etc. & 3.77 & .42 & .04 \\
Building with construction materials (blocks, Lego) & 3.75 & .44 & .04 \\
Playing in the sandpit & 3.73 & .51 & .05 \\
Drawing, colouring & 3.73 & .47 & .05 \\
Handiwork & 3.67 & .54 & .05 \\
Playing house & 3.64 & .54 & .06 \\
Romping around & 3.53 & .58 & .06 \\
Dressing up & 3.36 & .65 & .07 \\
Helping each other & 3.24 & .75 & .08 \\
Helping with 'chores' & 2.95 & .71 & .07 \\
\hline
\end{tabular}

$N=96 ; 5=$ very important, $1=$ not at all important that they would follow Nathalie's approach. They agreed that this would allow the children to let off steam and enjoy themselves. Only $2 \%$ minded the fact that playing outside would give rise to extra clearing up inside (sweeping up sand and dirt from outside), whereas $98 \%$ thought this was irrelevant to making their decision. When asked if they would make a different choice if the group would consist mainly of girls, 5\% answered positively, whereas $95 \%$ did not think they would act differently. Although a little more than half of the respondents do think that boys need more physical activity than girls, only 5\% think they would treat boys different from girls in this situation. So, these results underline our assumption that women daycare workers do not prefer the 'typical feminine' solutions.

In the second scenario, most respondents also did not chose the 'typical feminine' option (as constructed by the media-debates). In scenario 2, daycare worker Sharon resembles the stereotype of the rigid 'female' daycare worker who continuously restricts boys' need for activity and movement. Bernice, on the other hand, invites the noisy boys to move their race out into the corridor. Even more so, she says she would join the race. Sixty percent of

Table 4 Top-five of developmental activities.

\begin{tabular}{|c|c|c|c|c|c|c|}
\hline Developmental activity & First place & Second place & Third place & Fourth place & Fifth place & Sum \\
\hline Letting off steam outside (running, shouting etc.) & $35 \%(34)$ & $24 \%(23)$ & $21 \%(20)$ & $4 \%(4)$ & $4 \%(4)$ & $88 \%(85)$ \\
\hline Reading to children, singing & $24 \%(23)$ & $14 \%(13)$ & $29 \%(28)$ & $17 \%(16)$ & $6 \%(6)$ & $90 \%(86)$ \\
\hline Imaginative play with cars, trains etc. & $13 \%(12)$ & $9 \%(9)$ & $7 \%(7)$ & $12 \%(11)$ & $12 \%(11)$ & $53 \%(50)$ \\
\hline Romping around & $10 \%(10)$ & $4 \%(4)$ & $4 \%(4)$ & $10 \%(10)$ & $4 \%(4)$ & $32 \%(32)$ \\
\hline Helping each other & $8 \%(8)$ & $9 \%(9)$ & $5 \%(5)$ & $5 \%(5)$ & $13 \%(12)$ & $40 \%(39)$ \\
\hline Playing in the sandpit & $3 \%(3)$ & $8 \%(8)$ & $2 \%(2)$ & $2 \%(2)$ & $5 \%(5)$ & $20 \%(20)$ \\
\hline Building with construction materials (blocks, Lego) & $2 \%(2)$ & $9 \%(9)$ & $5 \%(5)$ & $14 \%(13)$ & $14 \%(13)$ & $44 \%(42)$ \\
\hline Drawing, colouring & $1 \%(1)$ & $3 \%(3)$ & $5 \%(5)$ & $8 \%(8)$ & $10 \%(10)$ & $27 \%(27)$ \\
\hline Playing house & $1 \%(1)$ & $3 \%(3)$ & $3 \%(3)$ & $4 \%(4)$ & $16 \%(15)$ & $27 \%(26)$ \\
\hline Dressing up & $1 \%(1)$ & $2 \%(2)$ & $2 \%(2)$ & $1 \%(1)$ & $6 \%(6)$ & $12 \%(12)$ \\
\hline Handiwork & $0 \%(0)$ & $13 \%(12)$ & $15 \%(14)$ & $19 \%(18)$ & $4 \%(4)$ & $47 \%(48)$ \\
\hline Helping with 'chores' & $0 \%(0)$ & $0 \%(0)$ & $0 \%(0)$ & $3 \%(3)$ & $1 \%(1)$ & $4 \%(4)$ \\
\hline
\end{tabular}

Frequencies are placed between brackets; $N=96$ 
respondents said that they would respond in the same way as Bernice, while 35\% favoured Sharon's 'typical feminine' option, and 5\% could not decide. More than half of the respondents (52\%) thought that, in this situation, sticking to rules was not so important. Playing in the corridor, in order to be able to play wildly, is considered a good idea by $91 \%$ of the respondents. The argument that 'it's best to play along with the boys, because they need more space for wild games' was considered unimportant by $76 \%$, and important by $18 \%$ of the respondents. It appears that rigidity in rules is not a general characteristic of these daycare workers, according to their own opinion. Therefore, scenario 2 also underlines our assumption that women daycare workers do not prefer the 'typical feminine' options, contrary to media's constructions.

\section{Discussion}

The purpose of this study involving 96 daycare workers has been to contribute to the social and academic debate on the effects of the feminization of early daycare. In the wake of the moral panic about boys' problems in schools, recent Dutch media-debates have been continuously accusing women daycare workers of creating a feminized atmosphere in the centers thereby seriously frustrating boys' need for physical activity. These debates are detracting from important changes in the professional identity of daycare workers. One of the interesting changes in daycare involves the increasing interest in pedagogical professionalism. In the past decades more and more emphasis is being placed on pedagogical aspects, alongside the traditional caring element of the work. It is not unlikely that this relatively recent and new orientation in daycare work has affected the professional image that daycare workers have of themselves. The study's objective was to examine to what extent the media stereotypes about women workers in daycare are an adequate account of what they themselves perceive as important aspects of their work. We hypothesized that women daycare workers would perceive 'feminine' qualities as more important to their work than other personal qualities (hypothesis 1), that they would employ a 'feminine' care orientation to their work, i.c. a 'motherly' care orientation (hypothesis 2), and that they also would employ a 'feminine' pedaogical orientation towards the development of the children, i.c. stimulating 'typical feminine' activities for girls as well as for boys (hypothesis 3 ).

Contrary to our first hypothesis $(1 \mathrm{a}-1 \mathrm{~d})$ women daycare workers did not rate the four qualities, rated by the mainstream media as 'typical feminine' characteristics as the most important characteristics for a good daycare worker. The personal characteristics deemed to be most important were 'loving children' and 'responsibility.' In earlier research into the professional image of primaryschool teachers (Hoogeveen 1999), these two personal characteristics were also cited as being the most important, by women as well as men early educators and daycare workers. The third most important personal quality cited was 'care.' As such, the respondents' image of themselves did not resemble the gendered stereotypical image of women daycare workers by the media, characterised by an exlusive focus on 'care,' 'modesty,' 'hominess' and 'precison.'

Secondly, we explored women daycare workers' care orientation. Based on Vogt's elaboration of the care-concept in a study among primary school teachers (Vogt 2002), we distinguished six aspects of the care orientation. For each aspect of Vogt's concept of care-orientation we formulated a specific hypothesis $(2 \mathrm{a}-2 \mathrm{e})$ assuming that women daycare workers in this study would rate the 'typical female' careorientation higher than the other aspects of Vogt's careorientation. Our findings show that respondents strongly emphasized the other, general aspects of care, such as 'being involved in the job' and 'feeling connected to children.' These aspects of care-orientation can be understood as necessary conditions for all sorts of pedagogical and educational professions. 'Being like a mother,' and 'being like a parent' were less popular among the women daycare workers, indicating that-contrary to hypothesis 2-a 'typical feminine' orientation towards care as a surrogate mother does exist among the respondents, but is seen as least important compared to the other, more general professional aspects of the care orientation.

Thirdly, it has been suggested in the Dutch media that the predominance of women in daycare has resulted in a bias towards stimulating 'typically female' activities in both boys and girls. We hypothesized that women daycare workers in this study, when choosing the developmental activities they considered to be most important, would prefer the so-called 'typical female' developmental activities (hypotheses 3a-3f). Our findings show that respondents did not prefer these so-called 'typical female' activities, but they chose all kinds of activities. Most popular, for girls as well as for boys, were outdoor play, e.g. 'letting off team outside, running, shouting,' inside play as 'reading to children, singing,' and 'imaginative play with cars, trains, etc.' These are developmental activities that were labelled by the media-debates on the feminisation of daycare as both 'typically female' activities ('reading to children, singing') and 'typically male' activities ('letting off steam outside,' 'imaginative games with cars and trains'). It appears then, that contrary to hypotheses $3 \mathrm{a}-3 \mathrm{f}$, women daycare workers consider it more important to offer young children a broad, differentiated range of developmental activities than the, by mainstream media constructed, activities as 'typical female' (Cameron et al. 1999; MacNaughton 2000). 
Neither did the choices made by the respondents in the two practical scenarios appear to support the claim of a 'typical feminine' approach in daycare centres. In reaction to the first scenario, respondents indicated that they consider it important that the boys (in the examples) were encouraged to enjoy 'letting off steam,' both indoors and outdoors. The women daycare workers also stated that they would treat girls in the same way; stimulating outdoor play was considered to be important for boys as well as for girls. The responses to the second scenario were also not in line with the gender stereotypical media images of women daycare workers. Most respondents chose the intervention response and engaged with the children in their play. This choice is contrary to the results of a recent study among Swedish preschool teachers, ten women and ten men preschool teachers (Sandberg and Pramling-Samuelsson 2005). The authors stated that women preschool teachers tend to value calm play while men preschool teachers accentuate the significance of physical development and engaged in childrens' play. In our study among 96 daycare workers, we did not find such a stereotypical play code: about $60 \%$ of our respondents did not prefer or prioritize calm play and participated in the childrens' play.

But we need more than opinions. It is often the case in social-scientific research that respondents give socially desirable answers. They can be swayed by the current social desirability of the idea that men and women are equally suited to working in daycare. Or, it is also possible that the daycare workers did not 'see' gender. In her 1991 study of an Australian early childhood teacher, MacNaughton stated that modern approaches to curriculum development in early childhood education can support patriarchal gender relations by skewing the teacher's gaze and that a feminist reconstruction of this gaze is needed (MacNaughton 1997). She hopes that, in another 20 years, it will no longer be possible to find early childhood educators who fail to 'see' gender. It could be possible that all daycare workers in this 2004 study provided very socially desirable answers. On the other hand, nowhere in this study we found evidence to support the idea of a stereotypical 'female' professional image within the daycare sector. We noted the same pattern in the reactions to the practical scenarios; a research method that provides better insight into the way daycare workers might judge and act in practice. In these scenarios the daycare workers did demonstrate a gender awareness in their communication and intervention patters with the children.

In line with historical trends in this work, the results of this study show a clear pedagogical orientation in daycare work, complementing the traditional care orientation. We would therefore conclude that continuing to reduce the characteristics and qualities needed in the daycare sector to 'female nature' is detracting from the developing pedagogical professionalism of the staff currently working in daycare centres.
Open Access This article is distributed under the terms of the Creative Commons Attribution Noncommercial License which permits any noncommercial use, distribution, and reproduction in any medium, provided the original author(s) and source are credited.

\section{Appendix}

Analysed items from the questionnaire (original language, Dutch)

10. Welke karaktereigenschappen zijn volgens u van belang voor een goede groepsleid(st)er? Per eigenschap kunt $\mathrm{u}$ aangeven hoe belangrijk $\mathrm{u}$ de eigenschap vindt. Omcirkel het cijfer van uw keuze.

$1=$ heel onbelangrijk

$2=$ beetje onbelangrijk

$3=$ niet belangrijk en niet onbelangrijk

$4=$ beetje belangrijk

$5=$ heel belangrijk

\begin{tabular}{llllll}
\hline actief zijn & 1 & 2 & 3 & 4 & 5 \\
bescheidenheid & 1 & 2 & 3 & 4 & 5 \\
gestructureerd zijn & 1 & 2 & 3 & 4 & 5 \\
huiselijkheid & 1 & 2 & 3 & 4 & 5 \\
humor, houden van grapjes, geintjes & 1 & 2 & 3 & 4 & 5 \\
intelligentie, slim zijn & 1 & 2 & 3 & 4 & 5 \\
van kinderen houden & 1 & 2 & 3 & 4 & 5 \\
verantwoordelijkheid & 1 & 2 & 3 & 4 & 5 \\
vindingrijkheid & 1 & 2 & 3 & 4 & 5 \\
zorgzaamheid & 1 & 2 & 3 & 4 & 5 \\
\hline
\end{tabular}

11. Geef bij de volgende stellingen an in hoeverre $u$ het er wel of niet mee eens bent.

$1=$ helemaal mee oneens

$2=$ beetje mee oneens

$3=$ niet mee eens en niet mee oneens

$4=$ beetje mee eens

$5=$ helemaal mee eens

Een goede groepsleid(st)er is als een moeder voor haar kinderen.

12345

Een goede groepsleid(st)er is erg betrokken bij het werk. 12345

Een goede groepsleid(st)er voelt zich verbonden met de kinderen.

12345

Een goede groepsleid(st)er moet proberen om als een ouder te zijn.

12345 
Een goede groepsleid(st)er knuffelt veel met de kinderen. 12345

Een goede groepsleid(st)er besteedt veel aandacht aan de lichamelijke verzorging van kinderen

\section{5}

12. Een belangrijke functie van het kinderdagverblijf is het bieden van ontwikkelingsmogelijkheden voor jonge kinderen. Hoe belangrijk vindt $\mathrm{u}$ onderstaande mogelijkheden?

Per mogelijkheid kunt $\mathrm{u}$ aangeven hoe belangrijk $\mathrm{u}$ dit vindt. Omcirkel het cijfer van uw keuze.

$$
\begin{aligned}
& 1=\text { heel onbelangrijk } \\
& 2=\text { beetje onbelangrijk } \\
& 3=\text { niet belangrijk en niet onbelangrijk } \\
& 4=\text { beetje belangrijk } \\
& 5=\text { heel belangrijk }
\end{aligned}
$$

\begin{tabular}{|c|c|c|c|c|}
\hline Ruimte om met elkaar te stoeien & 1 & 2 & 3 & \\
\hline Buiten kunnen rennen, springen en schreeuwen & 1 & 2 & 3 & 4 \\
\hline Bouwen met constructiemateriaal (blokken, duplo) & 1 & 2 & 3 & 4 \\
\hline Fantasiespel met auto's, trein & 1 & 2 & 3 & 4 \\
\hline $\begin{array}{l}\text { In de zandbak spelen (graven, scheppen, bouwen, } \\
\text { taartjes bakken) }\end{array}$ & 1 & 2 & 3 & \\
\hline Knutselen & 1 & 2 & 3 & \\
\hline Verkleden & 1 & 2 & 3 & 4 \\
\hline Voorlezen, zingen, (taal)spelletjes & 1 & 2 & 3 & 4 \\
\hline $\begin{array}{l}\text { Helpen met huishoudelijke klusjes (tafel dekken, } \\
\text { vloer vegen etc.) }\end{array}$ & 1 & 2 & 3 & \\
\hline Kleuren, tekenen & 1 & 2 & 3 & \\
\hline 'Huisje' spelen (bv. koken, eten, slapen & 1 & 2 & 3 & 4 \\
\hline $\begin{array}{l}\text { Elkaar helpen: bv. de oudere kinderen helpen } \\
\text { de jongere kinderen bij het jas/schoenen aantrekken }\end{array}$ & 1 & 2 & 3 & 4 \\
\hline
\end{tabular}

Geef uw top-vijf van meest belangrijke ontwikkelingsmogelijkheden. Kies uit bovenstaand lijstje.

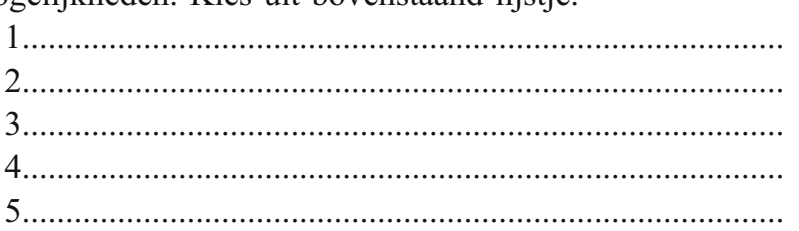

III Scènes uit de praktijk

Hieronder volgt een aantal scènes: gebeurtenissen die tijdens uw werk op het kinderdagverblijf kunnen voorvallen. Lees de scènes en beantwoord de vragen.

\section{Scène 1}

Het is een grijzige najaarsdag. Het is frisjes buiten, maar gelukkig regent het niet. In kinderdagverblijf De Zonnebloem zijn vandaag 12 kinderen in de peutergroep (2-4 jaar): 9 jongens en 3 meisjes. Vandaag zijn groepsleidsters Nathalie (21) en Linda (29) op de groep. Ze hebben net gezamenlijk fruit gegeten en de kinderen zijn nu aan het spelen. De kinderen zijn druk vandaag: er wordt veel geduwd en geroepen, er is af en toe ruzie en een traan. Linda en Nathalie vinden allebei dat ze iets moeten doen om de sfeer te herstellen.

Groepsleidster Linda stelt voor om met z'n allen te gaan kleien aan de grote tafel. Muziekje met vrolijke liedjes erbij, dan keert de rust vanzelf weer.

Groepsleidster Nathalie wil liever met de kinderen gaan buiten spelen. Even uitwaaien, wat bewegen, rennen en schreeuwen, dan zijn ze hun energie weer even kwijt. Het binnenspelen zal daarna ook weer plezieriger verlopen.

14. Wat zou $\mathrm{u}$ doen in dit geval: zoals Linda of zoals Nathalie?.

15. U kunt verschillende redenen hebben om te kiezen voor Linda of voor Nathalie. Hieronder noemen we een paar mogelijkheden. Wilt $u$ aangeven of voor $u$ de volgende redenen belangrijk of onbelangrijk zijn?

A Het is niet zulk lekker weer, grijs en 0
koud. Bovendien krijg je in de herfst
altijd veel zand, modder en bladeren
mee. Dus weer extra vegen en
schoonmaken.... wat een gedoe!
B In de groep zijn 9 jongens en 3 meisjes. 0
Jongens hebben meer behoefte om te
bewegen dan meisjes, dus je kunt ze
maar beter even buiten laten uitrazen
en rennen.
C Linda is 29 jaar, Nathalie is 21 jaar. 0
Linda is ouder en heeft meer
werkervaring dan Nathalie. Linda kan
dus beter inschatten wat het beste is
om te doen.

16. A Stel het waren 9 meisjes en 3 jongens (in plaats van 9 jongens en 3 meisjes), zou uw keuze voor Linda of Nathalie dan veranderen?

0 Nee, dan zou mijn keuze gelijk blijven

$0 \mathrm{Ja}$, dan zou ik kiezen voor

\section{Scène 2}

In de groepsruimte voor de peuters $(2-4$ jr. $)$ staat een verzamelbak waarin kartonnen doosjes, wc-rolletjes en dergelijke worden bewaard om mee te knutselen. Drie jongetjes hebben een doosje uit de bak gehaald en zeggen dat ze willen knutselen. Dat mag, maar eerst moet de 
tafel nog even worden afgeruimd. Ze moeten nog even wachten.

De jongetjes vinden dat niet erg. Niels roept: ik heb een race-auto! en gooit het doosje met een grote zwaai over de vloer, helemaal tot aan de andere kant van de ruimte. Jordi en Kevin joelen en juichen en al gauw zijn ze met zijn drieën bezig met een erg lawaaierige wedstrijd, waarbij de doosjes heen en weer 'racen.'

Groepsleidster Sharon: "Kevin, Niels en Jordi, jullie weten best dat de doosjes daar niet voor zijn. Kom maar gauw aan tafel om te knutselen, en als je dat niet meer wilt, leg dan de doosjes terug in de bak. Racen doe je maar met de autootjes, met wat minder geschreeuw alsjeblieft".

Groepsleidster Bernice: "Hee, een wedstrijd? Ik wist niet dat we hier een racebaan hadden! Weet je wat, laten we op de gang verder racen. Daar hebben we meer ruimte, dan kun je véél harder. Mag ik ook meedoen? Dan kies ik ook even een 'auto' uit".

17. Wat zou u doen in zo'n geval: zoals Sharon of zoals Bernice.

18. U kunt verschillende redenen hebben om te kiezen voor Sharon of voor Bernice. Hieronder noemen we een paar mogelijkheden.

Wilt $\mathrm{u}$ aangeven of voor $u$ de onderstaande redenen belangrijk of onbelangrijk zijn?

\begin{tabular}{|c|c|c|c|}
\hline & & Belangrijk & Onbelangrijk \\
\hline A & $\begin{array}{l}\text { Als groepsleid(st)er is het belangrijk } \\
\text { om in te spelen op wat kinderen zelf } \\
\text { aangeven te willen doen. Het is voor } \\
\text { de kinderen leuk als je met hun } \\
\text { zelfbedachte spel meedoet. }\end{array}$ & 0 & 0 \\
\hline B & $\begin{array}{l}\text { Ook peuters moeten weten dat je niet } \\
\text { zomaar alles kunt doen. De doosjes } \\
\text { waren bedoeld om mee te knutselen, } \\
\text { dan mogen de peuters er geen andere } \\
\text { dingen mee gaan doen. }\end{array}$ & 0 & 0 \\
\hline $\mathrm{C}$ & $\begin{array}{l}\text { Jongens houden van wilde spelletjes en } \\
\text { hebben meer beweging nodig dan } \\
\text { meisjes, daarom kan je beter met de } \\
\text { jongens gaan racen. }\end{array}$ & 0 & 0 \\
\hline D & $\begin{array}{l}\text { Het is verstandig om de kinderen die } \\
\text { iets willen doen dat druk en lawaaiig is, } \\
\text { ergens anders te laten spelen dan bij de } \\
\text { kinderen die zich concentreren op een } \\
\text { lastig werkje. Zo kan iedereen doen wat } \\
\text { hij wil zonder de anderen in de weg te } \\
\text { zitten. }\end{array}$ & 0 & 0 \\
\hline
\end{tabular}

Stel het waren allemaal meisjes die gingen racen met de wc-rolletjes. Zou uw keuze voor Sharon of Bernice dan veranderen?

0 Nee, dan zou mijn keuze hetzelfde blijven
0 Ja, dan zou ik kiezen voor

Analysed items from the questionnaire (translated into English)

10. Which personal characteristics do you think are important for a good daycare worker? Indicate the importance of each characteristic seperately. Encircle the digit of your choice.

$1=$ very unimportant

$2=$ somewhat unimportant

$3=$ neither important nor unimportant

$4=$ somewhat important

$5=$ very important

\begin{tabular}{llllll}
\hline Being active & 1 & 2 & 3 & 4 & 5 \\
Modesty & 1 & 2 & 3 & 4 & 5 \\
Structure & 1 & 2 & 3 & 4 & 5 \\
Hominess & 1 & 2 & 3 & 4 & 5 \\
Humor (like to make jokes) & 1 & 2 & 3 & 4 & 5 \\
Intelligence, being smart & 1 & 2 & 3 & 4 & 5 \\
Loving children & 1 & 2 & 3 & 4 & 5 \\
Responsibility & 1 & 2 & 3 & 4 & 5 \\
Resourcefulness & 1 & 2 & 3 & 4 & 5 \\
Caring & 1 & 2 & 3 & 4 & 5 \\
\hline
\end{tabular}

11. Indicate for each of the following statements to what extent you agree or disagree.

$1=$ totally disagree

$2=$ disagree somewhat

$3=$ neither agree nor disagree

$4=$ agree somewhat

$5=$ totally agree

A good daycare worker is like a mother for the children 12345

A good daycare worker is very much involved in her/his work

12345

A good daycare worker feels connected to the children 12345

A good daycare worker is like a parent to the children 12345

A good daycare worker often hugs and cuddles the children 12345

A good daycare worker pays a lot of attention to the physical care of children

12345 
12. Providing develomental activities for young children is concidered to be an important function of daycare centres. How do you rate the importance of the developmental activities listed below? For each item you can indicate the importance. Please encircle the digit of your choice.

$1=$ very unimportant

$2=$ somewhat unimportant

$3=$ neither important nor unimportant

$4=$ somewhat important

$5=$ very important

Opportunity to romp around

$\begin{array}{lllll}1 & 2 & 3 & 4 & 5\end{array}$

Letting off steam outdoors (running, shouting etc.)

$\begin{array}{lllll}1 & 2 & 3 & 4 & 5\end{array}$

Building with construction materials (blocks,

Lego etc.)

Imaginative play with cars, trains, etc.

Playing in the sandpit

Handiwork

Dressing up

Reading to children, singing, (language)games

Helping out with 'domestic chores' (laying the

table for snack time, sweeping floors etc.)

Drawing, colouring

Playing house

Helping each other (e.g. older children help the younger ones with putting on coats, shoes etc.)

Please indicate your personal top-five list of most important developmental activities, using the list above.

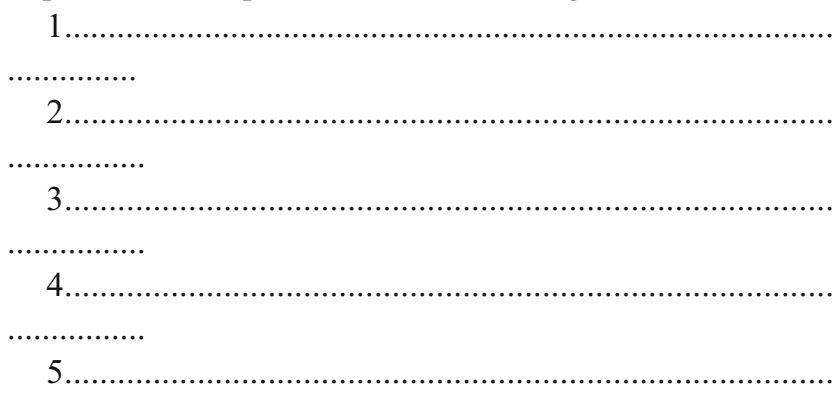

................

Practical scenarios:

Here we present two scenarios: situations that might happen during your work in daycare. Please read the scenarios and answer the questions below.

\section{Scenario 1:}

It is a dull autumn day. Although a bit cold, it is not raining. The 'Sunflower' daycare centre has 12 children in its toddler group (2-4 years old) today: 9 boys and 3 girls. Daycare workers Nathalie (21) and Linda (29) are on duty. They have just eaten fruit together and the children are playing. They are very excitable today: there is a lot of pushing and shouting, and a few arguments and tears. Linda and Nathalie both want to do something to improve the atmosphere.

Daycare worker Linda suggests that everyone sits at the big table to play with clay. They could play some cheerful music and restore the calm.

Daycare worker Nathalie would rather take the children outside to play. They could let off steam, run around and shout, and work off some of their excess energy. She thinks that this would also improve the atmosphere inside.

How would you respond in such a situation: like Linda or like Nathalie?

You may have several different reasons to choose for either Linda or Nathalie. Some possible reasons are given below. Please indicate if you think these reasons are important or unimportant:

\begin{tabular}{l}
\hline Amportant Unimportant \\
A The weather isn't too good: grey and \\
cold. Furthermore it's autumn so there is \\
lots of sand, mud and leaves coming into \\
our living room. This means extra \\
cleaning work... what a nuisance! \\
B There are 9 boys and three girls in the \\
group. Boys have a bigger need for \\
physical movement than girls, so it's \\
best just to let them go outside to run \\
around \\
C Linda is 29 years old, Nathalie is 21. \\
Linda is older en more experienced than \\
Nathalie. Therefore Linda is a better \\
judge in deciding what is best to do.
\end{tabular}

Suppose the group consisted of 9 girls and 3 boys (instead of 9 boys and 3 girls). Would this affect your choice between 'Linda' and 'Nathalie'?

0 No, this would make no difference

0 Yes, in this case I would choose.

\section{Scenario 2:}

In the area for toddlers ( $2-4$ years old), there is a chest that is used for storing cardboard boxes, toilet rolls and other materials for creative handiwork. Three boys have taken a box from the chest and say that they want to make something. This is fine, but only after the table has been cleared. They will have to wait.

The boys do not mind. Niels calls out: 'I've got a racing car!,' and gives his box a hard push so that it flies across the floor to the other end of the room. Jordi and Kevin start to yell and shout and soon all three boys are enjoying a wild, noisy race with the 'racing car' boxes.

Daycare worker Sharon: "Kevin, Niels and Jordi, you know perfectly well that the boxes are not meant for 
racing. Either come and sit at the table and make something with them, or put the boxes back in the chest. We have plenty of cars for racing, and you don't have to shout so loudly."

Daycare worker Bernice: "Hey, are you having a race? I didn't know we had a racetrack here! I have an idea, let's move the race out into the corridor. There's more room there, and we'll be able to go much faster. Can I join in? I'll just go and choose a "car."

How would you respond in such a situation: like Sharon or like Bernice?

You may have several different reasons to choose for either Sharon or Bernice. Some possible reasons are given below. Please indicate if you think these reasons are important or unimportant:

\begin{tabular}{l}
\hline \\
It's important for a childcare worker to Important Unimportant \\
follow the initiative of children. It's fun for \\
them if you participate in the game they \\
made up. \\
Toddlers too need to realise that you can't \\
do anything you like. The boxes were \\
meant to be used for creative handiwork, \\
so the kids aren't allowed to use them \\
differently. \\
Boys like wild games and need more \\
physical movement than girls, therefore \\
it's best to go racing with the boys. \\
It's a sensible thing to do: letting children \\
with a noisy game play somewhere away \\
from the children who are concentrating on \\
a difficult task. This way everyone can do \\
as they like without bothering the others.
\end{tabular}

Suppose it was the girls who wanted to play the racing game. Would this affect your choice between 'Sharon' and 'Bernice'?

0 No, this would make no difference.

0 Yes, in this case I would choose.

\section{References}

Browne, N. (2004). Gender equity in the early years. Maidenhead: Open University Press.

Cameron, C., Moss, P., \& Owen, C. (1999). Men in the nursery. Gender and caring work. London: Paul Chapman.

Clerkx, L. E., \& Pot, E. M. (1987). Lieve oppas gevraagd? Kinderopvang in Nederland door de jaren heen. [Sweet babysitter wanted? Daycare in The Netherlands throughout the years]. Nijkerk: Intro.

De Volkskrant. (2003). Oorlog aan de jongens [War to the boys]. De Volkskrant, March 11, p. 9.

Dowling, M. (2000). Young children's personal, social and emotional development. London: Paul Chapman.

Epstein, D., Elwood, J., Hey, V., \& Maw, J. (1999). Schoolboy frictions: Feminism and 'failing' boys. In D. Epstein, J. Elwood,
V. Hey, \& J. Maw (Eds.) Failing boys? Issues in gender and achievement (pp. 3-18). Buckingham: Open University Press.

Foster, V., Kimmel, M., \& Skelton, C. (2001). What about the boys?' An overview of the debates. In W. Martino, \& B. Meyenn (Eds.) What about the boys? Issues of masculinity in schools (pp. 1-23). Buckingham: Open University Press.

Francis, B., \& Skelton, C. (2005). Reassessing gender and achievement: Questioning contemporary key debates. New York: Routledge.

Ginsberg, A. E., Shapiro, J. P., \& Brown, S. P. (2004). Gender in urban education. Strategies for student achievement. Portsmouth, NH: Heinemann.

Hoogeveen, K. (1999). Het kunnen allemaal je eigen kinderen zijn. Leerkrachten basisonderwijs over hun beroep [They could all be your own children. Teachers in primary education on their profession] . Utrecht: Jan van Arkel.

Leids Dagblad. (2003). De meisjesnorm [The girls standard]. Leids Dagblad, January 25, p. 3.

MacNaughton, G. (1997). Feminist praxis and the gaze in the early childhood curriculum. Gender \& Education, 9, 317-327.

MacNaughton, G. (2000). Rethinking gender in early childhood education. London: Paul Chapman.

Murray, S. (1996). 'We all love Charles': men in childcare and the construction of gender. Gender \& Society, 10, 368-385.

NICHD Early Child Care Research Network (2002). Early child care and children's development prior to school entry: Results from the NICHD study of early child care. American Educational Research Journal, 39, 133-164.

NRC. (2003). Die lieve meisjes toch. Het Nederlandse onderwijs lijdt onder "vrouwelijke cultuur" [Oh, those sweet little girls. Dutch education suffers from a 'feminine culture']. $N R C$, May 3, p. 35.

NRC. (2004). Ook man kan goede voorbeeld geven [Men too, can show good example]. $N R C$, August 6, p. 3.

Noordhollands Dagblad, (2003). Meisjesnorm brengt jongens in problemen [Girls' standard leads to boys' problems]. Noordhollands Dagblad, February 8, p. 18.

Riksen-Walraven, M. (2000). Tijd voor kwaliteit in de kinderopvang [Time for quality in daycare] . Amsterdam: Vossiuspers.

Sandberg, A., \& Pramling-Samuelsson, I. (2005). An interview study of gender differences in preschool teachers' attitude towards children's play. Early Childhood Education Journal, 5, 297-305.

Singer, E. (1992). Child care and the psychology of development. London: Routledge.

Tavecchio, L. (2002). Van opvang naar opvoeding [The move from daycare to child raising] . Amsterdam: Vossiuspers.

Timmerman, M. C., \& Schreuder, P. R. (2005). Pedagogische professionaliteit in de kinderopvang: Een genderkwestie? [Pedagogical professionalism in daycare: A matter of gender?]. Pedagogiek, 25, 159-175.

Timmerman, M. C., \& Schreuder, P. R. (2008). Pedagogical professionalism and gender in daycare. Gender and Education, 1, 1-14.

van Essen, M. (1999). Strategies of women teachers 1806-1920. Feminization in Dutch elementary and secondary schools from a comparative perspective. History of Education, 28, 413-433.

van IJzendoorn, R., Tavecchio, L., \& Riksen-Walraven, M. (2004). De kwaliteit van de Nederlandse kinderopvang [Quality of Dutch daycare] . Amsterdam: Boom.

Vandenbroeck, M. (2004). In verzekerde bewaring. Honderdvijftig jaar kinderen, ouders en kinderopvang. [In safe custody. Hundred and fifty years of children, parents, and daycare]. Amsterdam: SWP.

Vogt, F. (2002). A caring teacher: Explorations into primary school teachers' professional identity and ethic of care. Gender and Education, 14, 251-264.

Volman, M. (2004). Jongens en juffen: Wat is het probleem? [Boys and female teachers: What is the problem?]. Pedagogiek, 24, 107-111.

Woltring, L. (2003). Jongenspedagogiek? Opvoeden met gevoel voor sekseverschillen [Boys-pedagogics? Raising children with an eye to gender differences]. Pedagogiek, 23, 175-181. 